\title{
Hydrological drought response to meteorological drought in the Iberian Peninsula
}

\author{
J. Lorenzo-Lacruz ${ }^{1, *}$, S. M. Vicente-Serrano ${ }^{1}$, J. C. González-Hidalgo ${ }^{2}$, \\ J. I. López-Moreno ${ }^{1}$, N. Cortesi ${ }^{2}$
}

${ }^{1}$ Department of Geoenvironmental Processes and Global Change, Pyrenean Institute of Ecology (CSIC), Campus de Aula Dei, PO Box 202, Zaragoza 50080, Spain

${ }^{2}$ Department of Geography, University of Zaragoza, C/ Pedro Cerbuna 12, Zaragoza 50009, Spain

\begin{abstract}
In this study we assessed the impact of meteorological droughts on streamflow droughts in 187 river basins of the Iberian Peninsula. For each basin we correlated the 1 mo to 48 mo standardized precipitation index (SPI) with the standardized streamflow index to assess the response time of streamflow droughts to the SPI, and to determine the best climatic time scale over which to monitor hydrological droughts. In addition, we analyzed the effects of dam construction and reservoir use on changes in the response of hydrological droughts. The analysis revealed 2 main types of hydrological drought response to meteorological drought: (1) a peak response pattern involving enhanced hydrological sensitivity at short SPI time scales, which largely characterized basins in the northern sector of the Iberian Peninsula, and (2) a sustained response pattern involving greater sensitivity to meteorological droughts at much longer time scales, which primarily characterized the central and southern basins of the Iberian Peninsula. Water management has significantly altered the natural hydrological response to meteorological droughts, delaying the impacts of precipitation deficits over long time scales, especially downstream of reservoirs used for irrigation purposes.
\end{abstract}

KEY WORDS: Hydrological drought · Meteorological drought · Drought time scales · Standardized precipitation index $\cdot$ Standardized streamflow index $\cdot$ Water management

\section{INTRODUCTION}

Analysis of the temporal dynamics of water resources in the Mediterranean basin is complex because of the high degree of natural variability in the climate (Mariotti \& Struglia 2002, Iglesias et al. 2007, García-Ruiz et al. 2011), the changes in land use that have occurred in the headwaters of the river basins (Vicente-Serrano et al. 2004a, Lasanta et al. 2005, Sluiter \& De Jong 2007), and the intensive regulation of water resources to supply urban areas and agriculture (Batalla et al. 2004, López-Moreno et al. 2009, Lorenzo-Lacruz et al. 2010). To assess the possible consequences of climate change for the future availability of water resources in the region it is necessary to understand the relationships between climate vari- ability and the occurrence of hydrological droughts in vulnerable regions, such as the Iberian Peninsula (IP).

There are many uncertainties in estimating the impacts of climate change processes on water resources (Raisanen 2007, Raje \& Mujumdar 2010, Alkama et al. 2011, Finger et al. 2012). These uncertainties are related to difficulties in establishing direct relationships between climate variability and hydrological variables (e.g. streamflow, lake levels, reservoir storage rates), which are a consequence of the influence of land use changes (Beguería et al. 2003) and varying water management strategies (López-Moreno et al. 2007). Moreover, other factors can modify the hydrological response to climate variability. It has been observed that longer water transit times occur in basins dominated by subsurface flow and aquifer 
recharge processes. This produces a slow response in terms of surface runoff generation, and, consequently, substantial temporal delays occur in water reaching the main river courses following rainfall events (Soulsby et al. 2010). Other factors that have to be taken into account are those related to snow accumulation and melting, as these are responsible for the delay between precipitation that occurs during winter and the streamflows in the following months; this can critically affect water resources availability during the dry season (Adam et al. 2009).

Assessing the availability of water resources requires consideration of the impacts of human influences on the hydrological cycle due to water regulation. For example, the combined effects of reservoir management and water extraction for irrigation purposes during the second half of the 20th century are estimated to have generated a decrease of $2.1 \%$ in the mean planetary river discharge (Biemans et al. 2011). Human perturbations make it difficult to distinguish climatic influences, particularly as the hydrological response to precipitation can vary significantly among basins and as a function of time (Elfatih et al. 1999, Pandey \& Ramasastri 2001, VicenteSerrano et al. 2011), because of the complexity and changing frequencies of climatic and hydrological variables (Skøien et al. 2003).

Drought is a multi-scalar phenomenon (McKee et al. 1995), with the effects of precipitation deficits (meteorological drought) becoming evident in different systems (e.g. surface and groundwater hydrology, agriculture) at different temporal scales. This is very important for quantifying and monitoring droughts, as the temporal scales over which precipitation deficits accumulate distinguishes different drought types; knowledge of these differences facilitates quantification of the delays between meteorological and hydrological droughts. Previous studies have shown that the response time with respect to preceding meteorological conditions is highly variable among regions and basins, and mainly depends on the physiographic characteristics of the basin (geology, topography, soils and vegetation), precedent meteorological conditions (evapotranspiration rates, snow cover and rainfall intensity), and water management strategies (Post \& Jakeman 1996, Vicente-Serrano \& López-Moreno 2005, LorenzoLacruz et al. 2010, Fleig et al. 2011).

This complexity highlights the need for a more in depth analysis of the ways in which streamflow responds to climate fluctuations at various time scales. Advances in this field are necessary to improve the assessment and forecasting of water resources in a global change context, but also to obtain a better understanding of the streamflow response to recent climatic variability. To date, some analyses have been done in this direction, revealing a prominent hydrological response to precipitation deficits at short time scales in unregulated basins (Szalai et al. 2000, Vicente-Serrano \& López-Moreno 2005, LorenzoLacruz et al. 2010, López-Moreno et al. 2013, VanLoon et al. 2012). Nevertheless, the aforementioned studies were restricted to small or independent river basins, lacking a broad spatial perspective which would allow comparability and an easier interpretation of the results. This study is a novel contribution to the analysis of the temporal response of streamflow to precedent climatic conditions at a regional scale, including most of the river basins of the IP. It also represents an attempt to explain the different types of hydrological responses to precipitation deficits in terms of water management (reservoir uses) and aquifer recharge-discharge processes.

In this study we analyzed the temporal response of hydrological droughts to precipitation deficits in 187 Iberian drainage basins, which we quantified using the standardized precipitation index (SPI) calculated at various time scales (1 to $48 \mathrm{mo}$ ). We thus analyzed the meteorological drought time scales that determine the occurrence of hydrological droughts, and assessed how water management strategies, reservoir use and basin lithology condition and alter the hydrological response to meteorological droughts on the IP.

The extensive hydrological dataset used in this study includes data on the majority of large basins on the IP and their main tributaries, and includes a wide variety of river regulation types. This enabled us to analyze hydrological responses to drought in both unregulated and regulated river basins.

\section{STUDY AREA}

The IP has a surface area of $583254 \mathrm{~km}^{2}$, and very contrasting relief features. The mountain ranges of the area are mainly distributed from west to east and, in some cases, reach altitudes of $3000 \mathrm{~m}$ above sea level. The relief has shaped the river network and the spatial configuration of the major basins of rivers flowing towards the Atlantic Ocean (the Minho, Douro, Tagus, Guadiana and Guadalquivir basins) and the Mediterranean Sea (the Segura, Júcar and Ebro basins) (see Fig. 1a). The location and topography of the IP, together with the effects of large-scale atmospheric circula- 


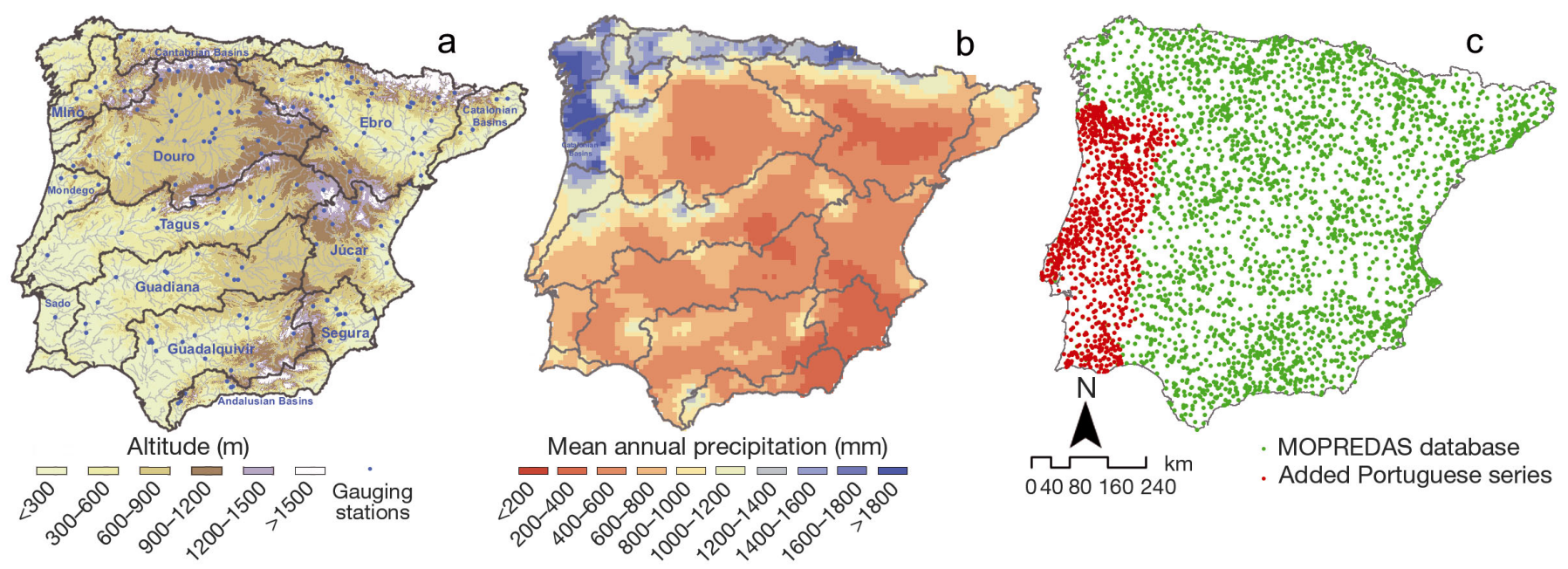

Fig. 1. (a) Topography of the Iberian Peninsula and location of the 187 gauging stations used in the study. (b) Spatial distribution of the mean annual precipitation (1945 to 2005) in Iberia. (c) Spatial distribution of the meteorological stations from which monthly data series in the monthly precipitation database of Spain and Portugal (MOPREDASP) were derived. Green dots: Spanish precipitation series (MOPREDAS, 2670 monthly series); red dots: Portuguese precipitation series (386 monthly series)

tion patterns (López-Bustins et al. 2008), generate a southeast to northwest gradient in annual precipitation (De-Castro et al. 2005, González-Hidalgo et al. 2011). Precipitation varies from $<300 \mathrm{~mm} \mathrm{yr}^{-1}$ in the southeast corner (e.g. the Murcia region) to $>1500 \mathrm{~mm} \mathrm{yr}^{-1}$ in the northwest (e.g. the Galicia region) (see Fig. 1b). The wide variety of precipitation regimes present in Iberia, some of them characterized by long dry spells, cause large variability in the duration and frequency of droughts among the various regions of the study area (Rico-Amorós 2004, Vicente-Serrano et al. 2004b, Vicente-Serrano 2006a, Vicente-Serrano \& López-Moreno 2006).

Moreover, dry summers and winter floods dominate the regime typical of Mediterranean rivers; this results in substantial inter-annual variability of streamflow, which produces long supra-seasonal droughts (Boix et al. 2010, Lorenzo-Lacruz et al. 2013).

River basins in the northern sector of the Atlantic watershed have hight streamflow values, with mean annual flows (measured at the most downstream streamflow gauges) of $10570 \mathrm{hm}^{3}$ for the Minho River, $13788 \mathrm{hm}^{3}$ for the Douro River and $12350 \mathrm{hm}^{3}$ for the Tagus River. In contrast, rivers in the southern sector of the Atlantic watershed (the Guadiana and Guadalquivir Rivers) have modest mean annual streamflows of 4039 and $3780 \mathrm{hm}^{3}$, respectively. Streamflows in basins in the Mediterranean watershed (the Segura, Júcar and Ebro basins) are generally low; the exception is the Ebro basin, which has abundant flow (mean $=12279 \mathrm{hm}^{3}$ ) that is generated in the Cantabrian Range and the Pyrenees. The unbalanced distribution of water resources within the IP and the rising demand for water have resulted in the construction of a dense network of dams and channels to optimize the use of available water resources. This is especially the case in the southern basins, where significant water regulation capacity by/at dams has been generated in the last $60 \mathrm{yr}$ (Arroyo-Ilera 2007). The intensive regulation of river systems on the IP is reflected in the large number of major reservoirs constructed during the 20th century (from 58 constructed in 1900 to 1195 constructed in 2000), which together account for a total storage capacity of $56500 \mathrm{hm}^{3}$ (Berga-Casafont 2003). This capacity is approximately equal to the mean annual streamflow of the 8 major rivers of the IP during the 1945 to 2005 period $\left(55850 \mathrm{hm}^{3}\right)$.

The IP has several characteristics that make it interesting for the study of droughts. It has high climatic variability, which explains the wide variety of hydrological regimes, and is frequently affected by meteorological droughts triggered by marked variability in atmospheric circulation and increasing water demand. Droughts on the IP are frequent; they detrimentally affect irrigated and rainfed agriculture, have negative impacts on industrial and tourism activities, cause water supply restrictions, and generate social and political conflicts (Causapé \& Clavería 2007, Quiroga et al. 2011, Ruiz-Sinoga \& León-Gross 2013). 


\section{DATA AND METHODS}

\subsection{Hydrological database: creation and validation}

To create a representative streamflow database for the entire IP, raw streamflow series from 1460 gauging stations distributed across the study area were obtained from the water agencies of Spain (Centro de Estudios Hidrográficos, Agència Catalana de l'Aigua, Agencia Andaluza del Agua and Augas de Galicia) and Portugal (Sistema Nacional de Informaçâo de Recursos Hídricos). Daily streamflow data for the IP were obtained from measurements of the daily water level at each gauging station, and the monthly river discharge at each gauge was integrated from the average daily discharge. The quality and length of the series is highly variable, and only the longest and most complete records were used to represent the major basins throughout the IP. The monthly series used encompassed the period from 1945 to 2005, with the aim of including any changes resulting from the intensive river regulation that took place in the second half of the 20th century. In total, 187 monthly streamflow series were selected, based on their record length and the percentage of data gaps (see Fig. 1a). A complete description of the creation and validation of this hydrological database is provided in Lorenzo-Lacruz et al. (2012).

\subsection{Precipitation dataset: quality control, homogenization and gap-filling process}

Analysis of the impacts of meteorological droughts on the occurrence of hydrological droughts was based on calculation of the correlations between series of the SPI (McKee et al. 1993) and the standardized streamflow index (SSI; Vicente-Serrano et al. 2012). For this reason it was necessary to use a robust and quality controlled monthly precipitation database, which encompassed the high spatiotemporal variability of precipitation on the IP (see Fig. 1b). We used the MOPREDAS (monthly precipiation database of Spain) database developed by González-Hidalgo et al. (2011), which is composed of 2670 monthly precipitation series of high quality (free of anomalous data and inhomogeneities) covering the period from 1945 to 2005 and the entire Spanish territory (see Fig. 1c), and added 386 monthly precipitation series for Portugal, provided by the Sistema Nacional de Informaçâo de Recursos Hídricos (http://snirh.pt/). The processes followed for quality control, homogenization and gap-filling of the Por- tuguese series were the same as those used by González-Hidalgo et al. (2011).

We generated a precipitation grid using the combined (3056) monthly precipitation series from 1945 to 2005 that were included in the database. For spatial interpolation we applied an ordinary kriging method, using a local interpolation that included 15 stations for each prediction, based on a spherical variogram (Isaaks \& Srivastava 1989). This provided 732 precipitation grid layers (one for each month included in the analysis) with a spatial resolution of $10 \mathrm{~km}$. Following generation of the grid we calculated the basin precipitation series as the mean precipitation value of all cells included in each drainage basin. In the case of small-size basins $\left(<100 \mathrm{~km}^{2}\right)$, the basin precipitation series correspond to the $10 \mathrm{~km}$ cell precipitation series where the basin lies. This generated 187 monthly averaged precipitation series (one for each drainage basin) covering the study period (1945 to 2005).

\subsection{Drought indices}

\subsubsection{SSI}

To obtain a hydrological index that enabled comparison of streamflow series in time and space, regardless of the magnitude of the series and the river regimes involved, we transformed the monthly streamflow series into a dimensional series of standardized anomalies. To obtain a reliable SSI that encompasses large variability in the statistical properties of the monthly data, the series were fitted to the most suitable probability distribution, according to the minimum orthogonal distance between the sample L-moments at site $i$ and the L-moment relationship for a specific distribution, selected from among the general extreme value, the Pearson Type III (PIII), the log-logistic, the log-normal, the generalized Pareto and the Weibull distributions. More details on the SSI calculation can be found in Vicente-Serrano et al. (2012).

\subsubsection{SPI}

In recent years the SPI has been among the most used drought indices worldwide for meteorological drought monitoring and impact assessment, and is considered to be a universal reference drought index by the World Meteorological Organization (Hayes et al. 2011). The main advantage of the SPI, in addition 
to its ease of calculation and minimum data requirements, is its ability to quantify drought severity at different time scales; this is essential for identifying variations in the hydrological response to meteorological droughts. The SPI transforms precipitation series into series of anomalies expressed as $z$-scores (with a mean equal to 0 and a standard deviation equal to 1), and accumulates the precipitation deficits of different temporal duration. In this study we used the algorithm developed by Vicente-Serrano (2006b) to calculate the SPI at various time scales (1 to $48 \mathrm{mo}$ ), basing the calculation on the fit of the precipitation series to the PIII distribution (see also Guttman 1999, Quiring 2009). From the precipitation series of each of the 187 basins, we calculated the SPI at time scales ranging from 1 to $48 \mathrm{mo}$.

\subsection{Statistical analysis}

To assess the impacts of meteorological droughts (quantified by means of the SPI) on streamflow droughts, we calculated the correlations (Pearson's r) between the series of the SPI and the SSI. This procedure produced 187 correlation curves between these indices at time scales from 1 to $48 \mathrm{mo}$. A principal component analysis (PCA) in S mode was used to summarize the response of hydrological droughts to meteorological droughts over the entire IP. The PCA technique is widely used by hydrologists to analyze the spatio-temporal variability of hydrological variables (Preisendorfer 1988, Kahya et al. 2008, MoránTejeda et al. 2011, Peterson et al. 2011); it facilitates retention of common features of the samples, and enables identification of local peculiarities. Using this approach we obtained a new set of non-correlated variables that were the linear combinations of the originals. The components were rotated to redistribute the explained variance and to obtain more physically robust patterns. This transformation was done using varimax rotation (White et al. 1991). The coefficients of such combinations ('loading factors') represent the correlations of the components with each original variable (curves of correlation between the SSI and the 1 to $48 \mathrm{mo}$ SPI). Identification of the maximum loading factor enabled us to classify each gauging station into the resulting groups.

Fig. 2 provides an explanatory overview of the analysis. It shows 2 curves (red and blue lines) of correlations between the SSI and the SPI at different time scales in 2 different basins. The curves summarize the relationship (in Pearson's $\mathrm{r}$ units) between the standardized streamflows (i.e. the SSI) and the
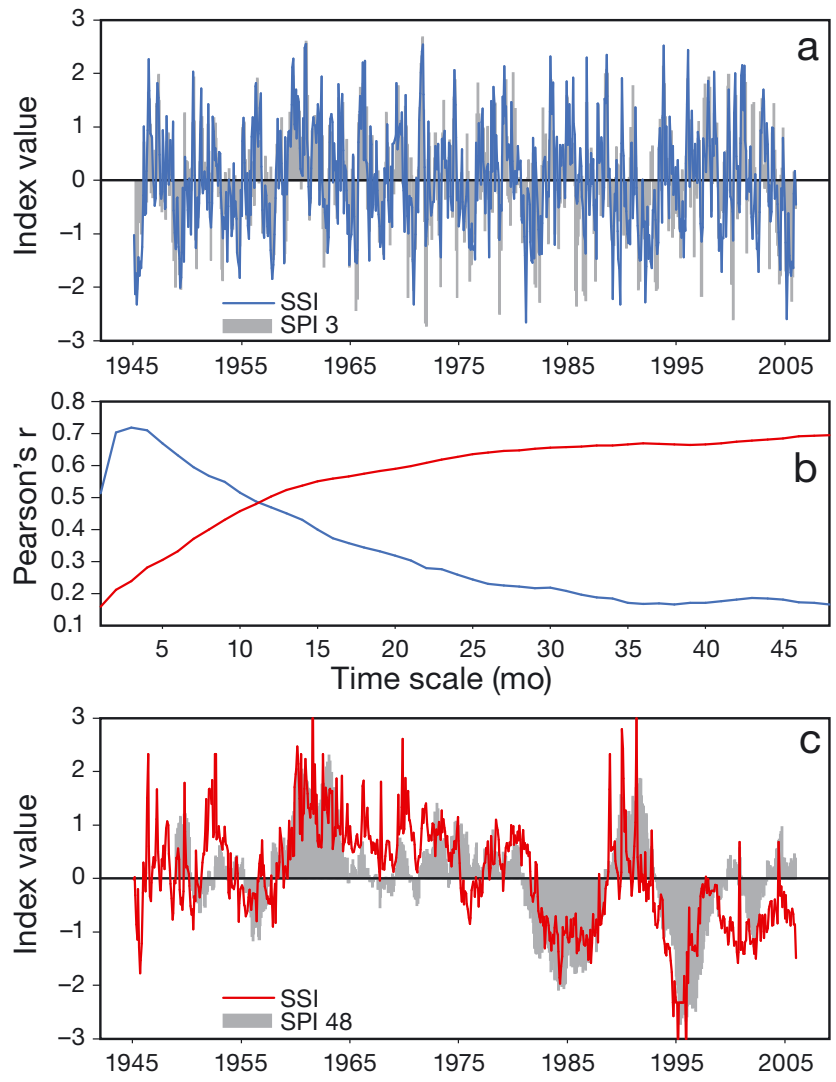

Fig. 2. (a) The hydrological response to drought in the Sabor River basin (Douro basin); temporal evolution of the standardized streamflow index (SSI) and the standardized precipitation index (SPI) at a 3 mo time scale. (b) Continuous correlation curve between the SSI and the SPI calculated at time scales of 1 to 48 mo for the Sabor (blue line) and Turia (red line) River basins. (c) The hydrological response to drought in the Turia River basin (Júcar basin); temporal evolution of the SSI and the SPI at a 48 mo time scale

accumulated precipitation anomalies (i.e. the SPI). Fig. 2 also shows the temporal evolution of the SSI and the SPI at the 3 mo time scale at a given gauging station (Fig. 2a), which coincides with the time scale of the highest correlation in the blue curve $(\mathrm{r}=0.71)$, and the evolution of the SSI and the SPI at the $48 \mathrm{mo}$ time scale at another gauging station (Fig. 2c), which represents the time scale with the highest correlation in the red curve $(r=0.69)$. This example clearly shows 2 contrasting responses of the basins to meteorological drought, with one basin mostly responding at short time scales of the SPI and the other basin responding at longer time scales.

There are 3 methods for determining the hydrological changes created by the damming of rivers: (1) the simulation of natural flows for comparison with the altered flows measured at a concrete gauging station (Maheshwari et al. 1995, Peters \& Prowse 2001); (2) 
the control station method, which compares river discharges upstream and downstream of dams (Assani et al. 2002); and (3) the monitoring of streamflows at the same gauging station, before and after the damming process (Richter et al. 1997, Erskine et al. 1999, Batalla et al. 2004). In this study we used the latter approach, performing the analysis using all the series included in the database and for the entire study period. We also distinguished between unregulated river basins, those rivers regulated during the study period (1945 to 2005), and rivers regulated prior to 1945, with the aim of investigating how changes caused by water regulation affect the hydrological response to meteorological drought. In the case of rivers regulated during the study period, we calculated the correlations for the periods prior to and following damming, which provided 2 curves of correlation between the SPI and the SSI. In each case we took into account the year of construction of the reservoir upstream of each gauging station considered.

As our analysis was based on a very extensive hydrological database, we used PCA in S mode to summarize the general patterns of streamflow response to meteorological droughts on the IP. The PCA was therefore based on the correlation values between the SSI and the SPI at different time scales, to enable grouping of basins with similar response times.

\section{RESULTS}

\subsection{General patterns}

Fig. 3a shows the results of the PCA based on the correlation curves between the SSI and the SPI at different time scales for each of the 187 gauging stations, independently of the degree of regulation. The map shows the spatial distribution of the basins and their classification according to their relationships to the various principal components. The graph next to the map shows the curves of correlation (factorial loadings of the components transformed into the original Pearson's $r$ units) between the SSI and the SPI at time scales from 1 to $48 \mathrm{mo}$; this summarizes the response of hydrological drought conditions to meteorological drought throughout the study area.

Two principal components (PC1 and PC2) together explained $91.12 \%$ of the total variance. PC1 explained $65.17 \%$ of the variance, and was characterized by short but intense responses over short time scales. The correlations were positive for all SPI time scales, although they were higher between 1 and 4 mo. The maximum correlation occurred at the 2 mo time scale $(\mathrm{r}=0.37)$, following which the correlations decreased markedly and ceased to be significant at the time scale of 14 mo. This pattern showed that the SSI values were mainly dependent on the SPI, which represented the rainfall during the previous 2 mo. Spatially, this pattern was distributed along the Minho basin, the Cantabrian basins, the tributaries of the left bank of the Douro River, much of the Ebro basin, the lower reaches of the Tagus River and specific small catchments in the Guadiana, Guadalquivir and Segura basins.

The second principal component explained $26 \%$ of the total variance, and the correlations were positive in all cases. However, although the SSI response was low for short SPI time scales, it increased considerably for SPI time scales in excess of 6 mo. The maximum correlation occurred at the time scale of $12 \mathrm{mo}$ ( $\mathrm{r}=0.55)$, although the correlations for longer time scales were significant. In this case the SSI values were particularly related to the amount of rainfall recorded during the previous $12 \mathrm{mo}$, although the role of precipitation in previous years was not negligible. This type of response characterized most of the Júcar, Guadiana, Guadalquivir and Segura basins, as well as specific sub-basins of the middle Tagus, Douro and Ebro basins.

\subsection{Response in non-regulated rivers: the role of lithology}

Fig. 3b shows the results of the PCA performed on the correlation curves between the SSI and the SPI at the scales of 1 to $48 \mathrm{mo}$ in the 58 unregulated basins in the study. The map shows the distribution of the basins and their classification according to their relationships to the various principal components. The graph adjacent to the map shows the correlation curves (factorial scores transformed into the original correlation units) that summarize the response of the 2 patterns obtained (explaining $87 \%$ of the total variance).

In this analysis PC1 explained $67.47 \%$ of the total variance and was characterized by a response of hydrological droughts to the SPI over short time scales. The correlations were positive for the time scales of 1 to $30 \mathrm{mo}$ and, as for the previous analysis the maximum correlation $(\mathrm{r}=0.4)$, again occurred at a time scale of $2 \mathrm{mo}$, following which the correlation decreased markedly and was non-significant beyond the 10 mo time scale. The basins represented by this pattern were the northern mountainous watersheds draining from the Cantabrian ranges, the Pyrenees, 

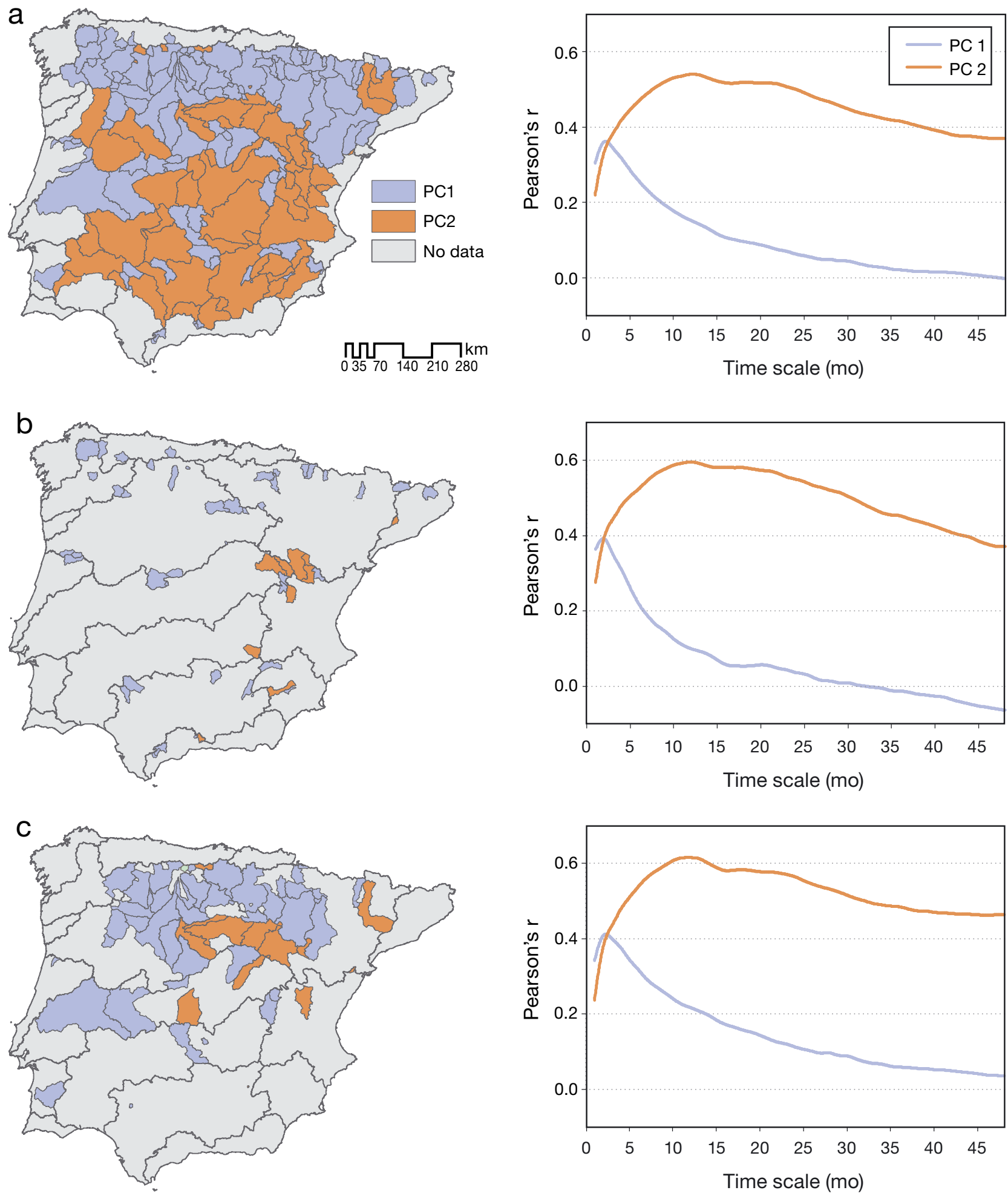

Fig. 3. Left: spatial distribution and classification of (a) all river basins included in the analysis, (b) only unregulated river basins and (c) only river basins regulated prior to 1945, based on the maximum loading factor for the selected principal components (PC). Right: scores for the 2 selected PCs expressed in the original units (Pearson's r) 
and the Central and Iberian systems, although some systems in the south also showed this pattern, including tributaries of the right bank of the Guadalquivir River and the Andalusian Mediterranean basin. The second principal component in this analysis (PC2) explained $19.29 \%$ of the total variance. The curve shows that low correlation values between the SPI and the SSI occurred at short time scales; the correlations increased from the 6 mo time scale to a maximum $(\mathrm{r}=$ $0.59)$ at the 12 mo time scale. This pattern represented the behavior of several basins in the southern Iberian ranges (headwaters of the Tagus, Gallo, Júcar and Alfambra Rivers) and the headwaters of the Guadina and Quípar Rivers (Segura basin). Nevertheless, because in this case the response to long SPI time scales involved unregulated basins, it is unlikely that the strong temporal inertia in the response to the SPI was driven by water regulation.

Fig. 4 shows the percentage of the surface area having limestone lithology among the unregulated basins that grouped into PC1 and PC2. Limestone is one of the most favorable materials for water infiltration: the porosity developed by fractures and rock alteration provides very favorable conditions for infiltration, storage and circulation of water. Furthermore, the presence of limestone in the headwaters of some basins enables aquifer recharge and discharge processes, which may account for the temporal aggregation of the hydrological response to meteorological drought conditions. The basins represented by PC1 in general have low percentages of limestone (mean $<10 \%$ ), explaining why these basins were associated with rapid responses in terms of surface runoff generation, which is accounted for by the predominant presence of impermeable lithologies. In

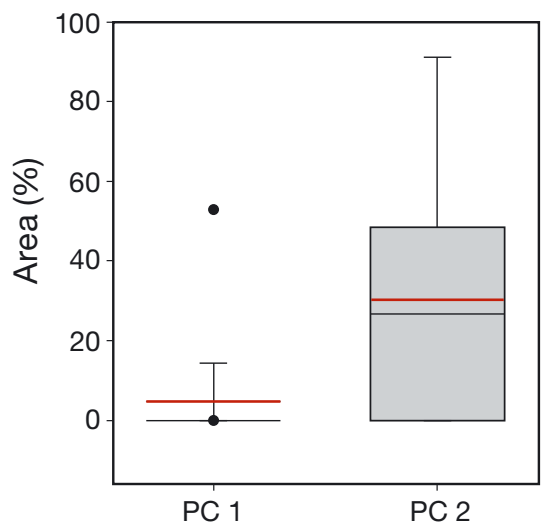

Fig. 4. Area comprising limestone lithology in the unregulated basins represented by the first and second principal components (PC1 and PC2, respectively). Black line: median; red line: mean; box borders: 25th and 75th percentiles; whiskers: 10th and 90th percentiles; dots: 5th and 95th percentiles contrast, the basins represented by PC2 have significant percentages of limestone cover (mean and median $>30 \%$ and $20 \%$, respectively); this supports the hypothesis that permeable lithologies favor the temporal aggregation of drought effects throughout the hydrological cycle.

\subsection{Effects of water management}

To investigate the hydrological response of regulated rivers to meteorological drought conditions, we assessed the response of those basins that had been regulated prior to the start of the study period (1945) and subsequently analyzed the changes in the response in those basins in which regulation was introduced during the study period (1945 to 2005). The relationship between the SSI and the SPI for the 2 principal components selected, extracted from the analysis of the correlation curves at different time scales in the 58 basins regulated prior to 1945, is shown in Fig. 3c. The patterns were similar to those observed previously for unregulated basins (see Fig. $3 b)$ : the first component $(70.2 \%$ of the total variance) was characterized by high correlations between the SSI and the SPI at short time scales and the second component ( $21.7 \%$ of the total variance) encompassed those river systems for which the response was marked by long temporal inertia in the response of the SPI to the SSI. The maximum correlation $(\mathrm{r}=0.4)$ occurred at the 2 mo time scale for the first component, while the second component showed a very sustained response, with correlations exceeding $r>0.5$ for the 6 to 30 mo time scales. The first component included several catchments in the middle Douro basin and associated tributaries on the right bank, the upper and middle sectors of the Ebro River, and the lower reaches of the Tagus River. The second principal component included the headwaters of the Douro River; the Jalón, Huerva and Segre systems in the Ebro basin; and specific catchments in the Júcar and Tagus basins.

Fig. 5 shows the correlation curves obtained from analysis of the 71 watersheds that were regulated during the study period. In each case we obtained 2 correlation curves between the SSI and SPI (at scales of 1 to $48 \mathrm{mo}$ ), one for correlations from 1945 to the year when the basin was regulated, and the other for correlations from the year in which damming was completed until 2005. The lighter colored curve represents the correlations before damming, and the darker curve, the response following damming. PC1 explained $32.9 \%$ of the variance and reflected a 

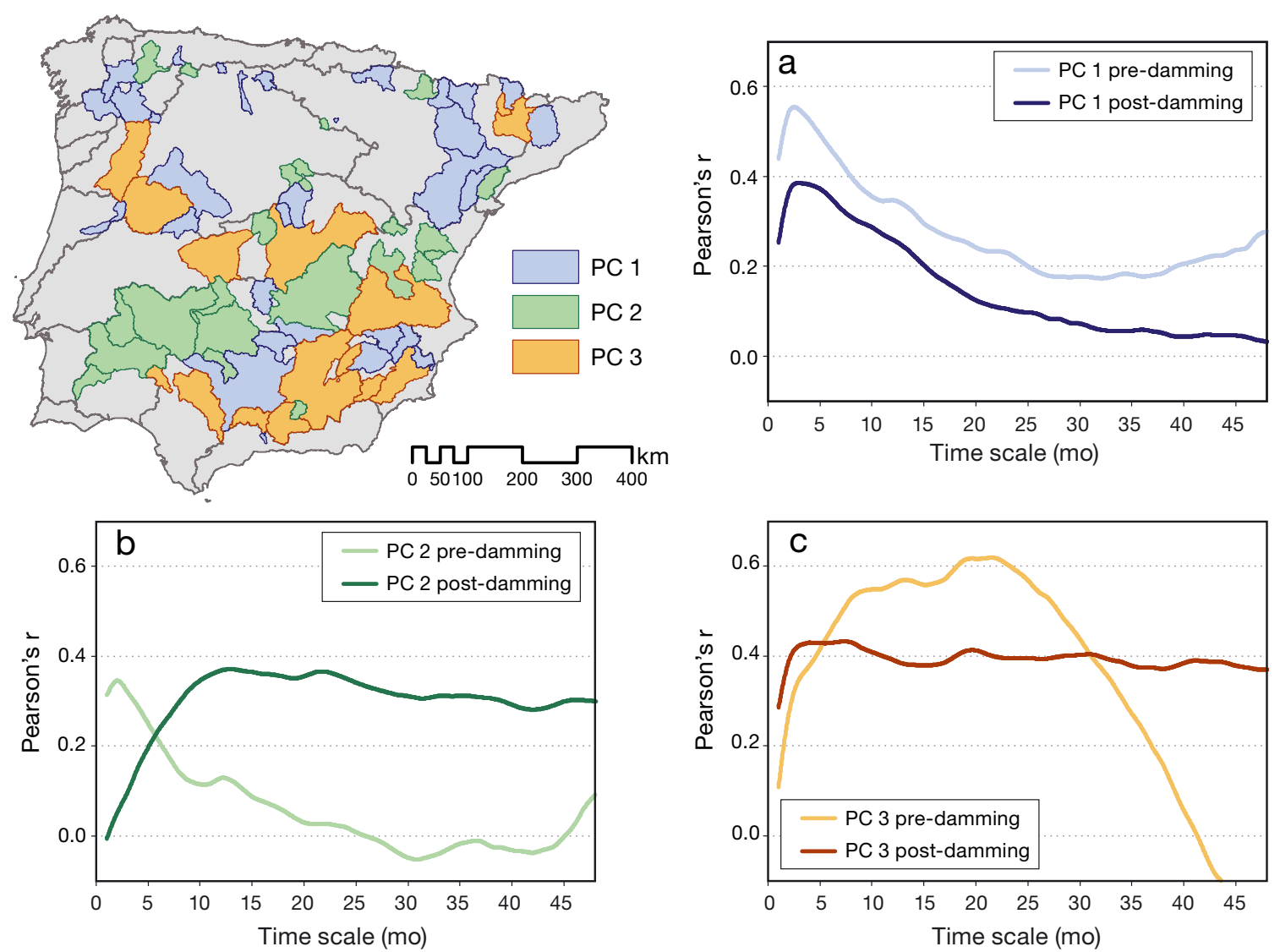

Fig. 5. Map: spatial distribution and classification of the river basins regulated between 1945 and 2005, based on the maximum loading factor for the selected principal components (PC1, PC2, PC3). Graphs: scores of the 3 selected PCs expressed in the original units (Pearson's r)

change in the observed response pattern at short time scales. Prior to regulation, these basins showed a marked response $(r>0.5)$ at time scales of 2 and 3 mo. The correlation curves for these basins had the same patterns following damming, but there was a decrease in the sensitivity of the basins to precedent rainfall, although the highest correlation still occurred at the 2 mo time scale. Of the 23 basins represented by this component, only 5 showed an increase in the magnitude of the correlations between the SSI and the SPI following upstream regulation. This component represented the Minho basin, numerous Pyrenean tributaries and the lower reaches of the Ebro River, the Tormes system in the Douro basin, the northern sector of the Segura basin and the middle sector of the Guadalquivir River. The correlation curves for PC2 (31.1\% of the variance) reflect a very large change in the response between the pre- and post-regulation periods. Prior to regulation, these basins showed greatest sensitivity at the 2 mo time scale, with correlations decreasing over longer time scales. Following regulation the streamflows responded at longer time scales, with higher correla- tions with the SPI time scales occurring between 8 and $38 \mathrm{mo}$; thus, they tended to conform to the second major general pattern observed, which was characterized by long time inertia in the hydrologic response to meteorological drought conditions. This second component characterized the response of hydrological droughts for most of the Guadiana basin, the northern sector of the Jucar basin, the Ebro River downstream of the Ribarroja-Mequinenza-Flix reservoir system, and basins that drain from the northern mountain ranges of the peninsula, including the Aragón River system in the Ebro basin. PC3 explained $19.6 \%$ of the variance and was related to basins that before damming showed a high correlation between the SSI and the SPI at medium and long time scales ( $r>0.5 ; 7$ to $28 \mathrm{mo}$ ). Following regulation these basins underwent a homogenization of the temporal inertia, with correlations of approximately $r=0.4$ over all time scales analyzed.

Fig. 6 includes box plots that show the SPI time scales for which the highest correlation with the SSI occurred between 1945 and 2005 in the 71 regulated basins prior to and following damming, classified by 
the use of the dam regulating each basin. In basins regulated by reservoirs used for hydropower generation (Fig. 6a), the regulation did not greatly alter the patterns of response to meteorological droughts. Although the time scale showing the maximum correlation increased with damming, the change was very small (from an average of 2 mo to an average of $5 \mathrm{mo}$ ). The response caused by regulation for hydropower generation use was typical of those basins represented by $\mathrm{PC} 1$ ( $70 \%$ of the river basins regulated exclusively for hydroelectric use were represented by this principal component; Fig. 5a); for these there was a small decrease in the correlation values, but only a minor shortening of the time scale at which the strongest hydrological response to climactic drought occurred.

However, where reservoirs were used for hydropower generation in combination with other uses,
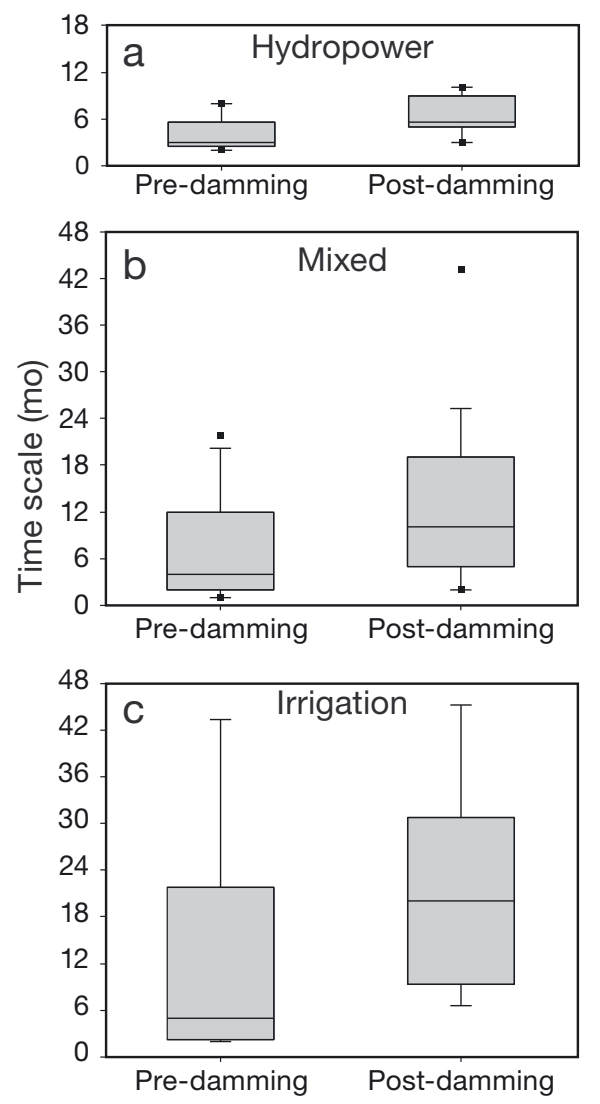

Fig. 6. Time scale of the standardized precipitation index (SPI) in which the maximum correlation between the standardized streamflow index and SPI was obtained in basins regulated between 1945 and 2005 (before and after the damming), classified according to the use of the reservoir which regulates each basin upstream in: (a) reservoirs for hydropower generation purposes, (b) reservoirs for mixed uses and (c) reservoir for irrigation purposes. Black line: median; box borders: 25th and 75th percentiles; whiskers: 10th and 90th percentiles; dots: 5th and 95th percentiles including urban supply or irrigation (Fig. 6b), the time scales at which the highest correlations between the SSI and the SPI were recorded changed considerably between the pre- and post-damming periods, from time scales of 2 to 12 mo to time scales of 5 to 20 mo. These types of reservoir were characterized by more sustained water storage over time (compared with hydropower generation), to enable the demand created by different uses to be met. This resulted in significant delays in the sensitivity of the streamflow to rainfall variability, which was probably closely related to the larger impoundment capacity. Thus, a significant positive correlation (Kendall's Tau $=0.25 ; \alpha<0.05$ ) was found between the impoundment ratio (IR; the ratio of the reservoir capacity to the mean annual runoff from each basin, expressed as a dimensionless decimal fraction; Batalla et al. 2004) and the SPI time scale at which the maximum correlation with the SSI was observed.

For reservoirs used exclusively for irrigation purposes, a greater lag occurred in the response of streamflows to the SPI. In these cases, prior to damming the SSI showed a maximum correlation with the SPI at short and medium time scales (the median corresponds to the 4 mo time scale), but after damming the median of the scale at which the maximum correlation occurred corresponded to the 19 mo time scale.

\section{DISCUSSION}

The analyses performed revealed 2 main patterns of streamflow response to drought over various time scales in both regulated and unregulated river basins. The dominant pattern was related to the first principal component in all the analyses performed, and was characterized by a brief and intense hydrological response to precipitation deficits over short time scales. This peak response pattern was observed in the northern part of the IP, and has previously been reported for several small basins in Hungary, where high correlations were found between streamflows and the SPI calculated at the 2 mo time scale (Szalai et al. 2000); a similar observation was made for the Aragon River basin in the central Pyrenees (Vicente-Serrano \& López-Moreno 2005). The rapid response is associated with the generation of intense precipitation runoff, which is favored in relatively small drainage areas having steep slopes and low permeability rock substrates (Vicente-Serrano \& López-Moreno 2005, López-Moreno et al. 2013). The second general pattern was that of a sustained re- 
sponse of streamflows to accumulated drought conditions. The accumulation of meteorological drought impacts on streamflows over long periods of time in the central and southern basins of the IP is consistent with the characteristics of hydrological droughts observed in this region by Lorenzo-Lacruz et al. (2013). However, in the case of regulated basins, the response pattern of a basin was found to depend on the water management strategies applied and the use of the reservoir and, in the case of unregulated basins, on the lithology of the basin.

For unregulated basins, the first principal component (representative of watersheds in the headwaters) showed a correlation between the SSI and the SPI at short time scales, which was likely to be associated with the occurrence of high runoff coefficients in areas dominated by non-permeable lithology. The second principal component reflected a hydrological response to meteorological drought conditions over long time scales. As noted by Lorenzo-Lacruz et al. (2010), the role of permeable lithologies is important in some of the areas represented by the second principal component. For these, a combination of permeability and the dominant flat moorland topography enables the establishment of discharge and recharge processes between river courses and groundwater aquifers. According to Soulsby et al. (2010), a dominance of freely draining substrates (such as limestone) in watersheds facilitates aquifer recharge and generates long transit times within a basin. This results in a weak response in terms of generation of precipitation runoff, and, consequently, the streamflow response to rainfall deficits occurs over longer time scales. In these unregulated basins the processes of recharge and groundwater discharge act as natural reservoirs, generating impacts similar to those produced by large-capacity reservoirs.

The 3 effects of the propagation of drought in the underground part of the hydrological cycle (Peters et al. 2003) were observed in the basins having a sustained hydrological response to meteorological drought: (1) the attenuation of deficits generated by meteorological drought during the aquifer recharge period (in the present study reflected in the low correlations between the SSI and the SPI at short time scales); (2) a greater delay in the streamflow response to precipitation deficits that generated little aquifer recharge in preceding months (in the present study reflected in high correlations between the SSI and the SPI at medium time scales); and (3) the synergistic effect produced by effects (1) and (2), which generate long multi-annual droughts (in the present study reflected in high correlations between the SSI and the SPI over long time scales).

Analysis of the impacts of meteorological drought on the basins regulated prior to 1945 revealed the same 2 major response patterns described above. This consistency was also reflected in the spatial distribution of the basins associated with each type of response, and is consistent with the results of LópezMoreno et al. (2013) for the Ebro basin. A significant correlation was found between the IR and the time scale at which the maximum correlation between the SSI and the SPI occurred, suggesting that the storage capacity is of major importance in explaining the temporal inertia observed for the regulated systems. This association supports the hypothesis that the use and capacity of a reservoir (smaller capacity reservoirs, usually related to hydropower production; larger capacity reservoirs, usually related to irrigation and urban supply) has an important role in modifying the impact of droughts and in explaining the temporal inertia observed in streamflow response times.

Analysis of the impacts of drought on the hydrological response in basins regulated between 1945 and 2005 enabled us to characterize the patterns of change directly related to water management and river damming. The first pattern of change in the hydrological response to meteorological droughts was characterized by a decrease in the sensitivity of streamflows to rainfall variability but no change in the temporal response, which continued to occur over short SPI time scales. The second pattern was characterized by a major change in the response, from high sensitivity at short time scales (peak response type) to a continuous response over much longer time scales (sustained response type). The results obtained for basins exhibiting the second pattern coincide with the findings of Vicente-Serrano \& López-Moreno (2005), who showed that streamflows in the Aragón River responded at short time scales, whereas the outflows from the Yesa reservoir responded over longer time scales; a similar phenomenon was observed in the headwaters of the Tagus River (Lorenzo-Lacruz et al. 2010). Collectively, these results demonstrate that regulation modifies the response times of streamflow to drought, and tends to smooth the impacts of meteorological drought, extending the time scales over which the impacts on streamflow conditions occur. The third pattern was characterized by an enhanced response at medium time scales prior to damming, whereas after damming the response of the streamflow to accumulated precipitation deficits was re-distributed among all 
the analyzed time scales, maintaining regular storage rates.

Although hydropower generation has historically been considered to be a non-consumptive use of water, it has been shown that the losses caused by evaporation (e.g. from reservoirs used for this purpose) are not negligible (Mekonnen \& Hoekstra 2012). The losses resulting from evaporation may explain the decreasing influence of the SPI on the behavior of the SSI, which was evident in a reduction in the magnitude of the correlations between the SSI and the SPI over short time scales following water regulation.

The multi-annual regulation associated with systems with great storage capacity, which are generally associated with irrigation use, is responsible for the large time lags between the occurrence of rainfall deficits and when they become evident in the streamflow downstream of reservoirs. However, the attenuating effect of reservoirs on the hydrologic response to meteorological drought conditions over short time scales generates a delayed and more sustained response over long time scales. This is likely to be related to the large amount of precipitation necessary to restore the original reservoir storage rates following an episode of prolonged drought.

Based on these results, there are several implications for water management. The response of streamflows to long time scales of precipitation variability in basins regulated by reservoirs used for irrigation purposes could suggest that the operation of large-sized reservoirs does not assure water supply under prolonged meteorological drought conditions. Moreover, the 'continuous demand' operational strategy followed by the water management agencies on the IP assumes that reductions in water availability will be directly reflected in the water supply. Large reservoirs may smooth drought impacts short-term, but, if the water demand for irrigation (even higher during meteorological drought episodes and also under current global warming scenario) cannot be adapted to uncertain water availability, the impacts of droughts would be most sustained and intense in the longterm. Contrary to reservoirs used for other purposes, those used as an irrigation supply show a greater relationship between the surface occupied by water and storage capacity; considering the increased temperature and evapotranspiration rates (Brunet et al. 2007, Espadafor et al. 2011), large-sized reservoirs would be expected to show a greater decrease in available water resources as a consequence of increased direct evaporation (Parry et al. 2000). Moreover, current climate change projections for the $21 \mathrm{st}$ century indicate a decrease in precipitation and a strong increase in potential evapotranspiration rates (CEDEX 2010). Thus, Moratiel et al. (2010) analyzed potential evapotranspiration projections for Spain at the end of the 21st century, and reported a likely increase of 80 to $430 \mathrm{~mm}$ relative to 1970-2000 levels, depending on the climate change scenario. Hydrological simulations under natural regimes for the whole IP show a strong decrease of streamflow during the 21st century. Estrela et al. (2012) indicated a mean global reduction of water resources by $17 \%$ under a $2.5^{\circ} \mathrm{C}$ increase in mean annual temperature and a decrease of $8 \%$ in mean annual precipitation. Given the strong influence of meteorological droughts on hydrological droughts identified in this study, problems of water scarcity may strongly increase in the future during the severe drought episodes that commonly affect the region (VicenteSerrano 2006b). Thus, although water regulation may reduce the direct influence of meteorological droughts on water resources, given the high storage capacity installed on the IP, it is expected that this regulation capacity will decline in the future under a scenario of more aridity, and the strong reduction of available water resources due to recent drought events (e.g. 1995, 2007 and 2012) will probably aggravate the situation in the near future.

\section{CONCLUSIONS}

In this study we analyzed the impact of meteorological drought and water regulation on the streamflow response in 187 Iberian drainage basins, by relating the SSI and the SPI calculated at various time scales. The analysis revealed 2 major patterns of hydrological response to the accumulated precipitation deficits at different time scales: (1) an intense peak response at short time scales, with the highest correlation at the 2 mo time scale, mainly associated with the northern basins of the IP; and (2) a sustained response over long time scales, associated with most of the central and southern basins of the IP.

Analysis of individual unregulated basins and those regulated prior to 1945 revealed the 2 patterns described above, although, in the case of the unregulated basins, the large temporal inertia observed in some was related to a high percentage of limestone lithology and not to water regulation. Those rivers that became regulated during the study period showed 3 patterns of change in terms of the response of the SSI at different time scales of the SPI. The first involved a decrease in the sensitivity of the stream- 
flow to meteorological drought, but no significant change in the time scales at which the highest correlations were recorded (short SPI time scales); this pattern was particularly associated with reservoirs used for hydropower generation. The second pattern resulting from river damming was characterized by a major change in the time scale at which the maximum correlation was recorded: from an intense response at short time scales to a sustained response over long time scales. This pattern was mainly associated with reservoirs used for irrigation purposes. The third pattern was related to homogenization of the response across all of the time scales analyzed, and was mainly associated with mixed-use reservoirs.

It has been demonstrated that large reservoirs used for mixed and irrigation purposes significantly alter the natural response of hydrological droughts to climatic droughts. The operation of this kind of reservoir mitigates the impacts of drought on streamflows at short time scales, at the expense of extending the impacts of drought over longer time scales. When persistent meteorological drought episodes occur, the ability of reservoirs to moderate their negative impacts decreases. This finding could have significant consequences for the future availability of water resources on the IP, as more frequent and severe drought episodes are expected during the 21st century (Feyen \& Dankers 2009). This will compound the uncertainty concerning the future state of water resources on the IP under conditions of global change.

Acknowledgements. We thank the Centro de Estudios Hidrográficos (CEDEX), Sistema Nacional de Informaçâo de Recursos Hídricos (SNIRH), Agència Catalana de l'Aigua, Agencia Andaluza del Agua and Augas de Galicia for providing the hydrological data used in this study. This work has been supported by a pre-doctoral fellowship by the Aragón Government (Spain) and by the research projects CGL2006-11619/HID， CGL2008-01189/BTE， CGL201127574-C02-02 and CGL2011-27536 financed by the Spanish Commission of Science and Technology and FEDER, EUROGEOSS (FP7-ENV-2008-1-226487) and ACQWA (FP7-ENV2007-1-212250) financed by the VII Framework Program of the European Commission, and 'La nieve en el Pirineo Aragonés y su respuesta a la variabilidad climática' and 'Efecto de los escenarios de cambio climático sobre la hidrología superficial y la gestión de embalses del Pirineo Aragonés' financed by 'Obra Social La Caixa' and the Aragón Government.

\section{LITERATURE CITED}

Adam JC, Hamlet AF, Lettenmaier DP (2009) Implications of global climate change for snowmelt hydrology in the 21st century. Hydrol Processes 23:962-972

Alkama R, Decharme B, Douville H, Ribes A (2011) Trends in global and basin-scale runoff over the late twentieth century: methodological issues and sources of uncertainty. J Clim 24:3000-3014

Arroyo-Ilera F (2007) Territorio, tecnología y capital. La regulación hidroeléctrica de los ríos españoles [1900-1970]. Treballs de la Societat Catalana de Geografía 63:39-70

Assani AA, Buffin-Bélanger T, Roy AG (2002) Analyse des impacts d'un barrage sur le régime hydrologique de la rivière Matawin (Québec, Canada). Rev Sci Eau 15: 557-574

Batalla RJ, Gómez CM, Kondolf GM (2004) Reservoirinduced hydrological changes in the Ebro river basin NE Spain. J Hydrol (Amst) 290:117-136

- Beguería S, López-Moreno JI, Lorente A, Seeger M, GarcíaRuiz JM (2003) Assessing the effect of climate oscillations and land-use changes on streamflow in the central Spanish Pyrenees. Ambio 32:283-286

Berga-Casafont L (2003) Presas y embalses en la España del siglo XX. Revista de Obras Públicas 3438:37-40

- Biemans H, Haddeland I, Kabat P, Ludwig F and others (2011) Impact of reservoirs on river discharge and irrigation water supply during the 20th century. Water Resour Res 47:W03509, doi:10.1029/2009WR008929

Boix D, García-Berthou E, Gascón S, Benejam L and others (2010) Response of community structure to sustained drought in Mediterranean rivers. J Hydrol (Amst) 383: 135-146

> Brunet M, Jones PD, Sigro J, Saladie O and others (2007) Temporal and spatial temperature variability and change over Spain during 1850-2005. J Geophys Res 112: D12117, doi:10.1029/2006JD008249

> Causapé J, Clavería I (2007) Drought as an agri-environmental determinant of irrigation land: the case of Bardenas (Spain). Environ Geol (Berl) 51:1213-1220

CEDEX (Courrier d'Entreprise à Distribution Exceptionnelle) (2010) Estudio de los impactos del cambio climático en los recursos hídricos y las masas de agua. Ficha 1. Evaluación del impacto del cambio climático en los recursos hídricos en régimen natural. Clave CEDEX 42-407-1-001. Informe técnico para ministerio de Medio Ambiente y Medio Rural y Marino, Madrid

De-Castro M, Martín-Vide J, Alonso S (2005) El clima de España: pasado, presente y escenarios de clima para el siglo XXI. Impactos del cambio climático en España. Ministerio Medio Ambiente, Madrid

> Elfatih A, Eltahir B, Yeh PJF (1999) On the asymmetric response of aquifer water level to floods and droughts in Illinois. Water Resour Res 35:1199-1217

Erskine WD, Terrazzolo N, Warner RF (1999) River rehabilitation from the hydrogeomorphic impacts of large hydroelectric power project: Snowy River, Australia. Regul Rivers Res Manag 15:3-24

> Espadafor M, Lorite IJ, Gavilán P, Berengena J (2011) An analysis of the tendency of reference evapotranspiration estimates and other climate variables during the last 45 years in southern Spain. Agric Water Manag 98:1045-1061

Estrela T, Pérez-Martin MA, Vargas E (2012) Impacts of climate change on water resources in Spain. Hydrol Sci J 57:1154-1167

> Feyen F, Dankers R (2009) Impact of global warming on streamflow drought in Europe. J Geophys Res 114:17116, doi:10.1029/2008JD011438

Finger D, Heinrich G, Gobiet A, Bauder A (2012) Projections of future water resources and their uncertainty in a glacierized catchment in the Swiss Alps and the subsequent 
effects on hydropower production during the 21st century. Water Resour Res 48:W02521, doi:10.1029/2011WR 010733

Fleig AK, Tallaksen LM, Hisdal H, Hannah DM (2011) Regional hydrological drought in north-western Europe: linking a new regional drought area index with weather types. Hydrol Processes 25:1163-1179

> García-Ruiz JM, López-Moreno JI, Vicente-Serrano SM, Lasanta-Martínez T, Beguería S (2011) Mediterranean water resources in a global change scenario. Earth Sci Rev 105:121-139

González-Hidalgo JC, Brunetti M, De-Luis M (2011) A new tool for monthly precipitation analysis in Spain: MOPREDAS database (monthly precipitation trends December 1945-November 2005). Int J Climatol 31: 715-731

Guttman NB (1999) Accepting the standardized precipitation index: a calculation algorithm. J Am Water Resour Assoc 35:311-322

> Hayes M, Svoboda M, Wall N, Widhalm M (2011) The Lincoln declaration on drought indices: universal meteorological drought index recommended. Bull Am Meteorol Soc 92:485-488

Iglesias A, Garrote L, Flores F, Moneo M (2007) Challenges to manage the risk of water scarcity and climate change in the Mediterranean. Water Resour Manage 21:775-788

Isaaks EH, Srivastava RM (1989) An introduction to applied geostatistics. Oxford University Press, Oxford

Kahya E, Kalayci S, Piechota TC (2008) Streamflow regionalization: case study of Turkey. J Hydrol Eng 13:205-214

Lasanta-Martínez T, Vicente-Serrano SM, Cuadrat-Prats JM (2005) Mountain Mediterranean landscape evolution caused by the abandonment of traditional primary activities: a study of the Spanish Central Pyrenees. Appl Geogr 25:47-65

- López-Bustins JA, Martín-Vide J, Sánchez-Lorenzo A (2008) Iberia winter rainfall trends based upon changes in teleconnection and circulation patterns. Global Planet Change 63:171-176

> López-Moreno JI, Beguería S, Vicente-Serrano SM, GarcíaRuiz JM (2007) Influence of the North Atlantic Oscillation on water resources in central Iberia: precipitation, streamflow anomalies and reservoir management strategies. Water Resour Res 43:W09411, doi:10.1029/2007WR 005864

> López-Moreno JI, Beguería S, Vicente-Serrano SM, GarcíaRuiz JM, Portela M, Betamio A (2009) Dam effects on droughts magnitude and duration in a transboundary basin: the lower River Tagus, Spain and Portugal. Water Resour Res 45:W02405, doi:10.1029/2008WR007198

> López-Moreno JI, Vicente-Serrano SM, Zabalza J, Beguería S, Lorenzo-Lacruz J, Azorin-Molina C, Morán-Tejeda E (2013) Hydrological response to the climate variability at different time scales: a study in the Ebro basin. J Hydrol (Amst) 477:175-188

- Lorenzo-Lacruz J, Vicente-Serrano SM, López-Moreno JI, Beguería S, García-Ruiz JM, Cuadrat JM (2010) The impact of droughts and water management of various hydrological systems in the headwaters of the Tagus River (central Spain). J Hydrol (Amst) 386:13-26

> Lorenzo-Lacruz J, Vicente-Serrano SM, López-Moreno JI, Morán-Tejeda E, Zabalza J (2012) Recent trends in Iberian streamflows (1945-2005). J Hydrol (Amst) 414/415: $463-475$

Lorenzo-Lacruz J, Morán-Tejeda E, Vicente-Serrano SM,
López-Moreno JI (2013) Streamflow droughts in the Iberian Peninsula between 1945 and 2005: spatial and temporal patterns. Hydrol Earth Syst Sci 17:119-134

Maheshwari BL, Walker KF, McMahon TA (1995) Effects of regulation on the flow regime of the River Murray, Australia. Regul Rivers Res Manag 10:15-38

> Mariotti A, Struglia MV (2002) The hydrological cycle in the Mediterranean region and implications for the water budget of the Mediterranean Sea. J Clim 15:1674-1690

McKee TBN, Doesken J, Kleist J (1993) The relationship of drought frequency and duration to time scales. In: Proc 8th Conf on applied climatology. American Meteorological Society, Anaheim, CA, p 179-184

McKee TBN, Doesken J, Kleist J (1995) Drought monitoring with multiple time scales. In: Proc 9th Conf on applied climatology. American Meteorological Society, Dallas, TX, p 233-236

Mekonnen MM, Hoekstra AY (2012) The blue water footprint of electricity from hydropower. Hydrol Earth Syst Sci 16:179-187

Morán-Tejeda E, López-Moreno I, Ceballos-Barbancho A, Vicente-Serrano SM (2011) Evaluating Duero's basin (Spain) response to the NAO phases: spatial and seasonal variability. Hydrol Processes 25:1313-1326

Moratiel M, Durán JM, Snyder RL (2010) Responses of reference evapotranspiration to changes in atmospheric humidity and air temperature in Spain. Clim Res 44: $27-40$

Pandey RP, Ramasastri KS (2001) Relationships between the common climatic parameters and average drought frequency. Hydrol Processes 15:1019-1032

Parry M, Parry C, Livermore M (eds) (2000) Valoración de los efectos potenciales del Cambio Climático en Europa (Informe ACACIA de la Comisión Europea, Resumen y Conclusiones). Universidad de Castilla-La ManchaIberdrola, Toledo

Peters DL, Prowse T (2001) Regulation effects on the lower Peace River, Canada. Hydrol Processes 15:3181-3194

Peters E, Torfs PJJF, van Lanen HAJ, Bier G (2003) Propagation of drought through groundwater-a new approach using linear reservoir theory. Hydrol Processes 17: 3023-3040

> Peterson HM, Nieber JL, Kanivetsky R (2011) Hydrologic regionalization to assess anthropogenic changes. J Hydrol (Amst) 408:212-225

Post DA, Jakeman AJ (1996) Relationships between catchment attributes and hydrological response characteristics in small Australian mountain ash catchments. Hydrol Processes 10:877-892

Preisendorfer RW (1988) Principal component analysis in meteorology and oceanography. Elsevier, New York, NY

Quiring SM (2009) Developing objective operational definitions for monitoring drought. J Appl Meteorol Climatol 48:1217-1229

> Quiroga S, Garrote L, Iglesias A, Fernández-Haddad Z and others (2011) The economic value of drought information for water management under climate change: a case study in the Ebro basin. Nat Hazards Earth Syst Sci 11: 643-657

> Raisanen J (2007) How reliable are climate models? Tellus, Ser A, Dyn Meterol Oceanogr 59:2-29

Raje D, Mujumdar PP (2010) Reservoir performance under uncertainty in hydrologic impacts of climate change. Adv Water Resour 33:312-326

Rico-Amorós AM (2004) Sequías y abastecimiento de agua 
potable en España. Boletín de la AGE 37:137-181

Richter BD, Baumgartner JV, Braun DP (1997) How much water does a river need? Freshw Biol 37:231-249

Ruiz-Sinoga JD, León-Gross T (2013) Droughts and their social perception in the mass media (southern Spain). Int J Climatol 33:709-724

Skøien JO, Blösch G, Western AW (2003) Characteristics space scales and timescales in hydrology. Water Resour Res 39:1304, doi:10.1029/2002WR001736

Sluiter R, De Jong M (2007) Spatial patterns of Mediterranean land abandonment and related land cover transition. Landscape Ecol 22:559-576

Soulsby C, Tetzlaff D, Hrachowitz M (2010) Are transit times useful process-based tools for flow prediction and classification in ungauged basins in montane regions? Hydrol Process 24:1685-1696

Szalai S, Szinell CS, Zoboki J (2000) Drought monitoring in Hungary. In: Wilhite DA, Sivakumar MVK, Wood DA (eds) Early warning systems for drought preparedness and drought management. World Meteorological Organization, Lisbon, p 182-199

> Van Loon AF, Van Huijgevoort MHJ, Van Lanen HAJ (2012) Evaluation of drought propagation in an ensemble mean of large-scale hydrological models. Hydrol Earth Syst Sci 16:4057-4078

Vicente-Serrano SM (2006a) Spatial and temporal analysis of droughts in the Iberian Peninsula [1910-2000]. Hydrol Sci J 51:83-97

Vicente-Serrano SM (2006b) Differences in spatial patterns of drought on different time scales: an analysis of the

Editorial responsibility: Gouyu Ren,

Beijing, China
Iberian Peninsula. Water Resour Manag 20:37-60

> Vicente-Serrano SM, López-Moreno JI (2005) Hydrological response to different time scales of climatological drought: an evaluation of the standardized precipitation index in a mountainous Mediterranean basin. Hydrol Earth Syst Sci 9:523-533

> Vicente Serrano SM, López-Moreno JI (2006) The influence of atmospheric circulation at different spatial scales on winter drought variability through a semiarid climatic gradient in north east Spain. Int J Climatol 26:1427-1456

> Vicente-Serrano SM, González-Hidalgo JC, de Luis M, Raventós J (2004a) Drought patterns in the Mediterranean area: the Valencia region (eastern Spain). Clim Res 26: $5-15$

> Vicente-Serrano SM, Lasanta T, Romo A (2004b) Analysis of the spatial and temporal evolution of vegetation cover in the Spanish Central Pyrenees, the role of human management. Environ Manag 34:802-818

Vicente-Serrano SM, López-Moreno JI, Gimeno L, MoránTejeda E, Lorenzo-Lacruz J, Beguería S, Azorín-Molina C (2011) A multiscalar global evaluation of the impact of ENSO on droughts. J Geophys Res 116:D20109, doi:10. 1029/2011JD016039

Vicente-Serrano SM, López-Moreno JI, Beguería S, Lorenzo-Lacruz J, Azorín-Molina C, Morán-Tejeda E (2012) Accurate computation of a streamflow drought index. J Hydrol Eng 17:318-332

> White D, Richman H, Yarnal B (1991) Climate regionalization and rotation of principal components. Int J Climatol $11: 1-25$

Submitted: November 5, 2012; Accepted: July 4, 2013 Proofs received from author(s): November 21, 2013 